\title{
CHAPTER D: STRUCTURAL GEOLOGY OF THE MOUNT FAIRPLAY-LADUE RIVER AREA
}

Alec D. Wildland ${ }^{1}$ and Travis J. Naibert ${ }^{1}$

\section{INTRODUCTION}

During the 2019 field season, the Mineral Resources section of the Alaska Division of Geological \& Geophysical Surveys (DGGS) conducted helicopter-supported bedrock geologic mapping of the Mount Fairplay-Ladue River region, a 4,800 $\mathrm{km}^{2}$ area of the Yukon-Tanana Upland of eastern Alaska. DGGS geologists collected 549 structure measurements, discussed by section below based on the planar feature type, and where appropriate, subdivided by host units. The majority are metamorphic foliations and fold-axial planes. Limited measurements of linear features, such as fold axes, stretched minerals, and intersections lineations, are recorded where observed. Measurements of bedding, fault surfaces, joint surfaces, and vein walls are also limited. Complete field descriptions and locations for station numbers cited can be found in Naibert and others (2020b). Our new geologic mapping (Twelker and others, 2021) extensively revises the known extent of metamorphic terrane boundaries, igneous rocks, and faults. Analysis of the new structural data was undertaken to test prior workers' metamorphic history and tectonic interpretations for the region, and it provides insights into local structural features within the context of their host unit.

Field observations of metamorphic assemblages in our map area suggest a regional stacking order, from bottom to top, including Paleozoic amphibolite-facies gneiss and amphibolite of the parautochthonous Lake George assemblage, Proterozoic to Mississippian partially retrograded amphibolite-facies allochthonous Yukon-Tanana Terrane (YTT) rocks of the Ladue River unit, and Permian greenschist-facies metavolcanic Yukon-Tanana Terrane rocks of the Klondike assemblage (Twelker and others, 2021). The Yukon-Tanana Upland is an area of generally poor exposure, however, previous workers have interpreted a complex polydeformational history throughout eastern Alaska and Yukon, Canada. There are currently three recognized deformational events prior to and since the Permian (Beranek and others, 2011; Dusel-Bacon and others, 1995; Hansen and Dusel-Bacon, 1998). The oldest deformation occurred during west-dipping Late Permian to Triassic subduction beneath the YTT when it was still distal to North America. Permian $\mathrm{U}-\mathrm{Pb}$ crystallization ages of intrusive rocks support this event known as the Klondike orogeny and it is responsible for the formation, deformation, and metamorphism of the Klondike assemblage, along with the magmatism observed in Yukon and locally in eastern Alaska (Beranek and others, 2011). Subsequent Jurassic margin-parallel contraction thrust the allochthonous terranes northwest and structurally over the parautochthonous Lake George assemblage. Top-to-the-northwest shear is variably recorded in both the lower and upper-plate assemblages from this period of thrusting (Hansen and Dusel-Bacon, 1998). Finally, mid-Cretaceous extension juxtaposed the structurally lower parautochthonous assemblages and the allochthonous units. Top-to-the-southeast shear is dominantly recorded in the Lake George assemblage and is locally observed in the allochthon (Fortymile River assemblage and Ladue River unit) near the boundary with Lake George (Berman and others, 2007; Hansen and Dusel-Bacon, 1998; Staples and others, 2016).

The cooling history of the metamorphic assemblages in and around the map area has been constrained by ${ }^{40} \mathrm{Ar} /{ }^{39} \mathrm{Ar}$ thermochronology, which often represents a mappable discontinuity in eastern Alaska (Dusel-Bacon and others, 2002). These cooling ages are likely a signature of metamor-

${ }^{1}$ Alaska Division of Geological \& Geophysical Surveys, 3354 College Rd., Fairbanks, Alaska 99709-3707 
phism which accompanied the deformational events as discussed above. The parautochthonous Lake George assemblage yields Cretaceous cooling ages (ca. 100-120 Ma) (Pavlis and others, 1993; Naibert and others, 2020a). This age range coincides with exhumation and juxtaposition of the Lake George assemblage with assemblages of the YTT (Pavlis, 1989; Hansen, 1990; Hansen and Dusel-Bacon, 1998). The allochthonous assemblages of the YTT near the Ladue River generally yield Triassic to Jurassic ${ }^{40} \mathrm{Ar} /{ }^{39} \mathrm{Ar}$ cooling ages (Jones and Benowitz, 2020) interpreted to record cooling during thrusting of allochthonous rocks structurally over pericratonic North America (Dusel-Bacon and others, 2002; Jones and others, 2017; Naibert and others, 2020a; Pavlis and others, 1993; Solie and others, 2019). The ${ }^{40} \mathrm{Ar} /{ }^{39} \mathrm{Ar}$ thermochronology ages are consistently found within these assemblages and have become defining features.

\section{DISCUSSION OF STRUCTURAL MEASUREMENTS}

The majority of structure measurements in the field area are metamorphic-tectonic foliations and to a lesser extent axial plane, fold axis, and mineral lineations. This report will discuss these data in the context of their respective assemblages as mapped in the field area.

\section{Metamorphic and Tectonic Foliation}

The Lake George assemblage represents the parautochthonous North American craton in the field area. The poles to foliation vary substantially in trend with consistent average moderate to steep plunges. These data do not show obvious signs of folding; such as girdle patterns or multiple clusters (fig. 1A). These folding patterns may have been disrupted by locally observed crenulation cleavage. The allochthonous rocks of the Ladue River unit cover a substantial portion of the map area. Foliation measurements are similar to foliations in the Lake George assemblage with moderately to steeply plunging poles to foliation (fig. 1B). There are also no discernible patterns or clusters. The Permian Klondike assemblage is ubiquitously greenschist-facies and is variably described as chloritic schist, greenstone, and lesser quartz-muscovite schist. The spatial extent of Klondike assemblage in eastern Alaska is under investigation, but in our field area it is the structurally highest portion of the allochthonous Yukon Tanana terrane, overlying the Ladue River unit. The mean vector of foliation poles plots slightly to the southwest compared to the Lake George assemblage and Ladue River unit mean vectors (fig. 1C). Some dispersion of foliation orientations may be due to tilting associated with post-metamorphic high-angle faults.
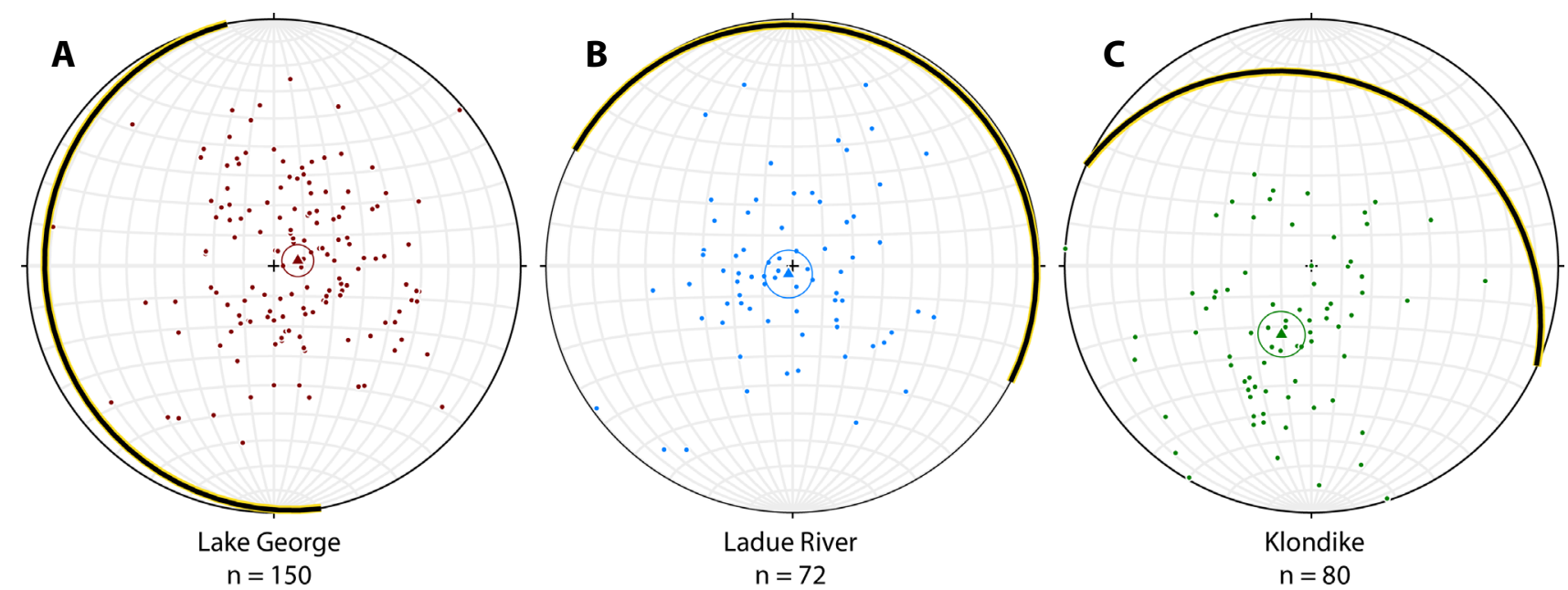

Figure 1. Equal-area stereonet plots of poles to foliation and average foliation planes (black lines highlighted in yellow) for: (A) Lake George assemblage (brown): average plane strikes 169 and dips 8; (B) Ladue River unit (blue): average plane strikes 298 and dips 3; and, (C) Klondike assemblage (green): average plane strikes 294 and dips 25. 


\section{Folding}

The scattered foliation data of the Lake George assemblage may indicate that there are not enough measurements to resolve folding at the map scale, or that the scale of folding differs substantially from the map scale. This is at odds with field observations of folding within outcrops. Both meterscale open (60-120 degree) folds and centimeterto meter-scale recumbent isoclinal folds were observed in the main metamorphic foliation of the Lake George assemblage (fig. 2A). Even though these folds are dominantly asymmetric, a consistent fold vergence was not noted in the field. However, the axial planes strike from northeast to southeast and on average dip moderately to shallowly to the south, which implies northward vergence (fig. 3A). Eighty percent of fold axis measurements have an average trend northeast-southwest. Mineral and stretching lineations, primarily from K-feldspar porphyroclasts, are typically northwest-southeast, locally northeast-southwest, and are moderately to shallowly plunging (fig. 4A). The northeast-southwest-trending fold axes mentioned above appear to correspond to northwest-southeast mineral lineations commonly found within the Lake George assemblage. The distribution of foliations, axial planes, and linear features is difficult to relate to

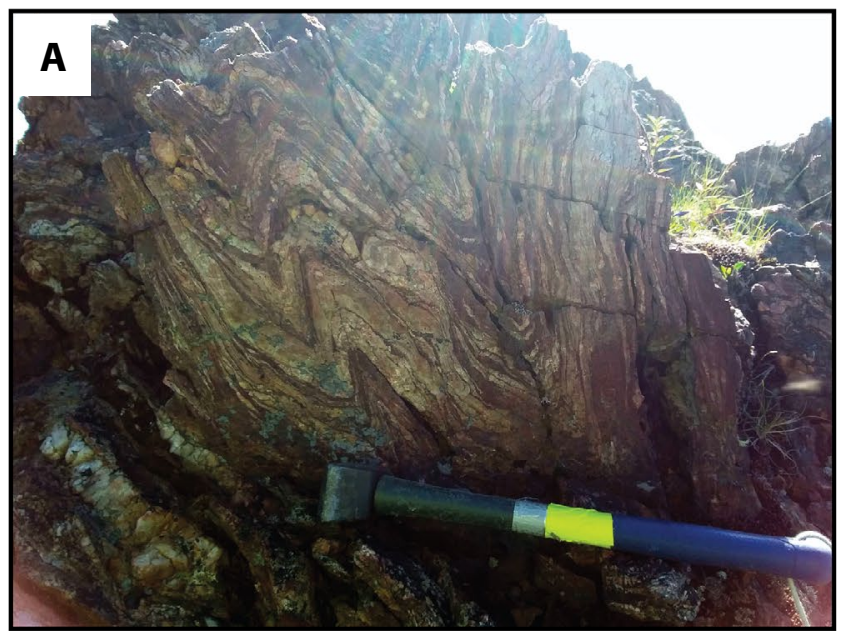

deformational events owing to poor exposure throughout the field area.

Map-scale folding is not clearly recorded in the generally scattered foliation data collected in the allochthonous rocks of the Ladue River unit. Observed folds in the field are dominated by outcrop-scale open folds (fig. 2B). Isoclinal and slightly asymmetric folding of the dominant foliation was also observed locally. Folds within this unit often have northwest vergence. Half of the axial planes strike east-west and dip shallowly to the south similar to stations within the Lake George assemblage (fig. 3B). A notable difference is that the Ladue River unit stations have southeast-trending fold axes compared to southwest-trending fold axes in the Lake George assemblage. Several unique axial plane measurements with north-northwest strikes and steep dips were collected at one location in the northwest area of the map (19KS334). Associated fold axes trend to the northwest with shallow plunges. Stretching lineations within the Ladue River unit are all shallowly plunging with two possible sub populations which trend north-northeast and east-west, respectively (fig. 4B).

Axial plane strikes measured within the Klondike assemblage vary from northwest to southwest and are steeply to moderately dipping to the north as opposed

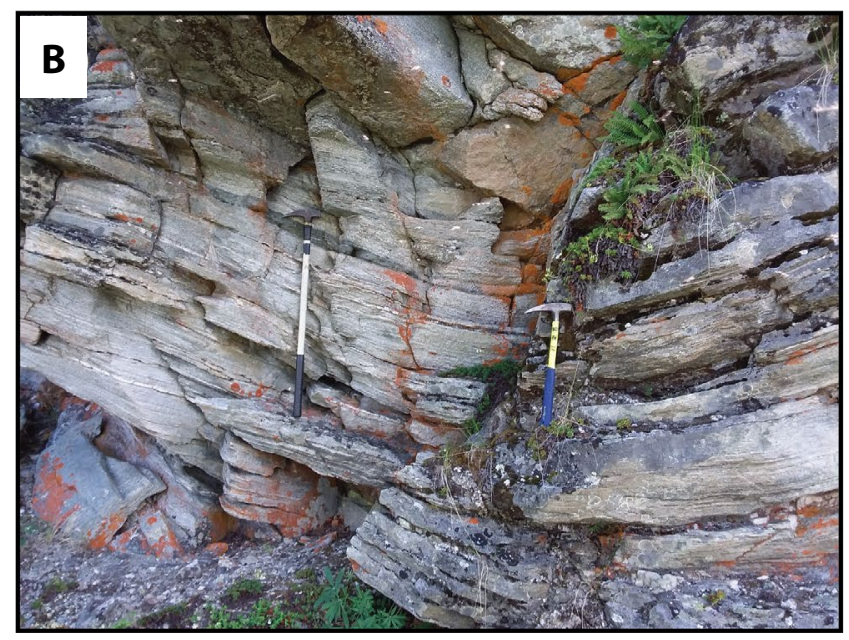

Figure 2. Observed folding: (A) station 19ADW201; Lake George assemblage metasedimentary rocks (MDlgs) highlights an early foliation that is isoclinally folded within the dominant later foliation of the Lake George assemblage; (B) station 19JAL082; metamorphic rocks of the Ladue River unit (MDpo) displaying large-scale open folds. 

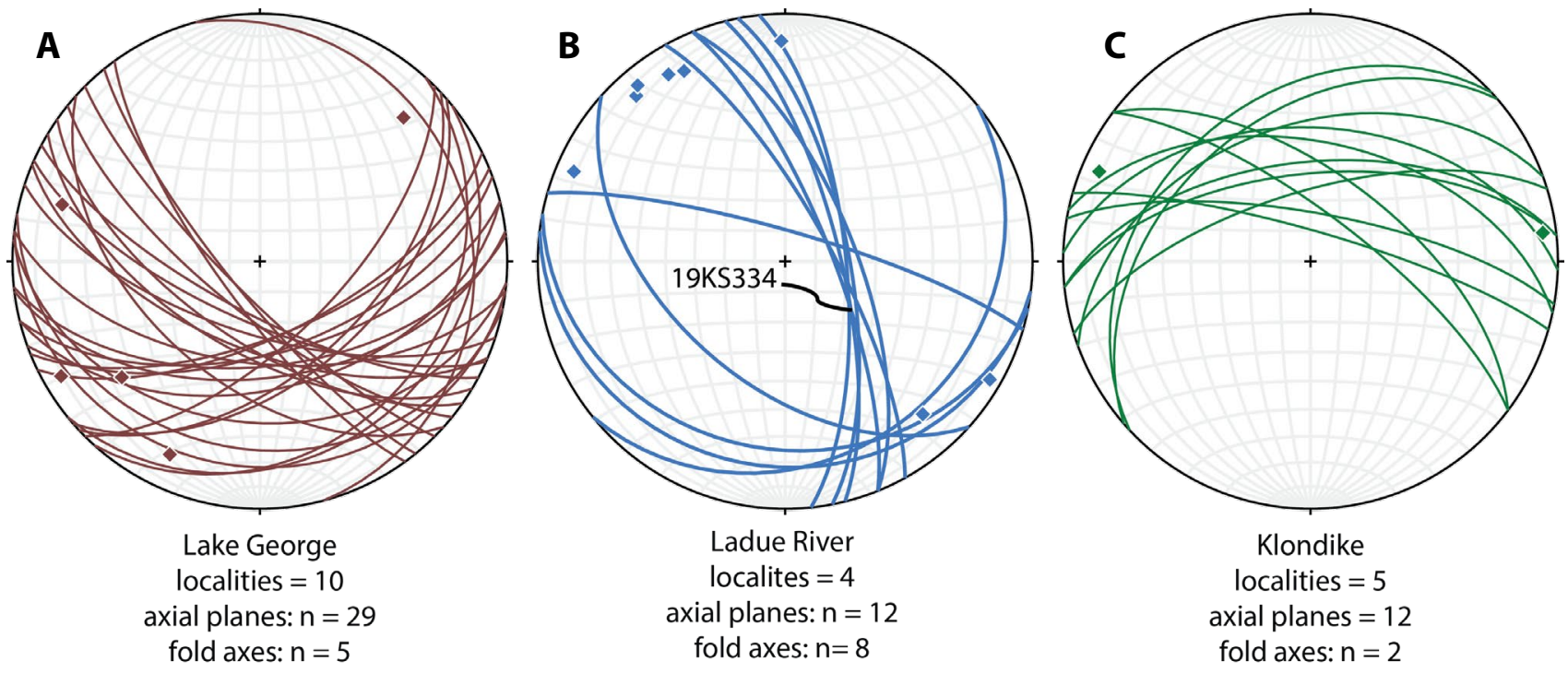

Figure 3. Equal-area stereonet plots of axial planes and fold axes: (A) Lake George assemblage (brown); (B) Ladue River units (blue); and, (C) Klondike assemblage (green).
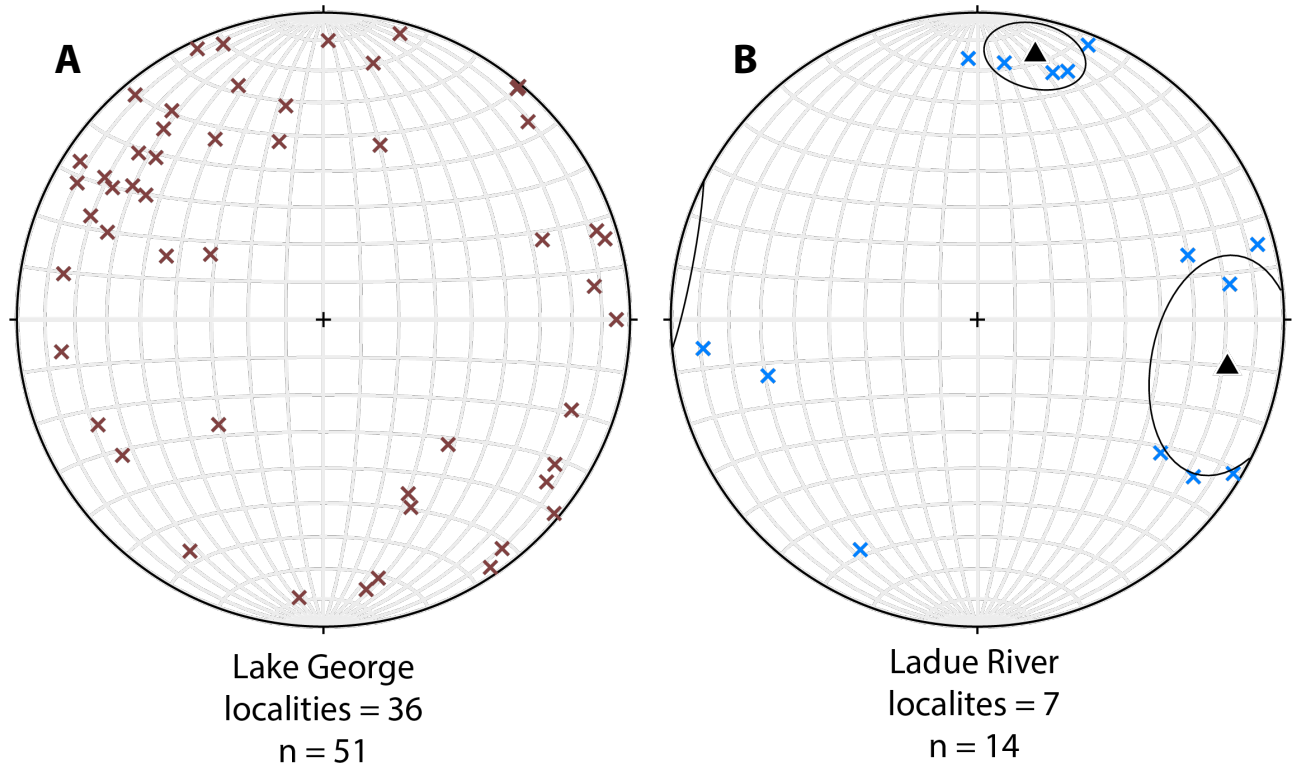

Figure 4. Equal-area stereonet plots of mineral and stretching lineations: (A) Lake George; and, (B) Ladue River. Mean vector of two sub-populations indicated by black triangles.

to the southward dipping axial planes observed in the other units. The two recorded fold axis measurements within the Klondike trend east-west (fig. 3C). Folding is asymmetric with possible vergence to the south.

\section{Shear Zone and Ductile Kinematics}

The geology of the map area is divided into the allochthonous Yukon-Tanana Terrane (Ladue River unit and Klondike assemblage) and parau- tochthonous North America (Lake George assemblage), each having separate Mesozoic structural histories suggested by geochronology, differences in ages of magmatism, and metamorphic P-T histories (Beranek and Mortenson, 2011; Dusel-Bacon and others, 1995, 2002, Hansen and Dusel-Bacon, 1998; Pavlis and others, 1993; Staples and others, 2016). The Klondike assemblage is distinguished 


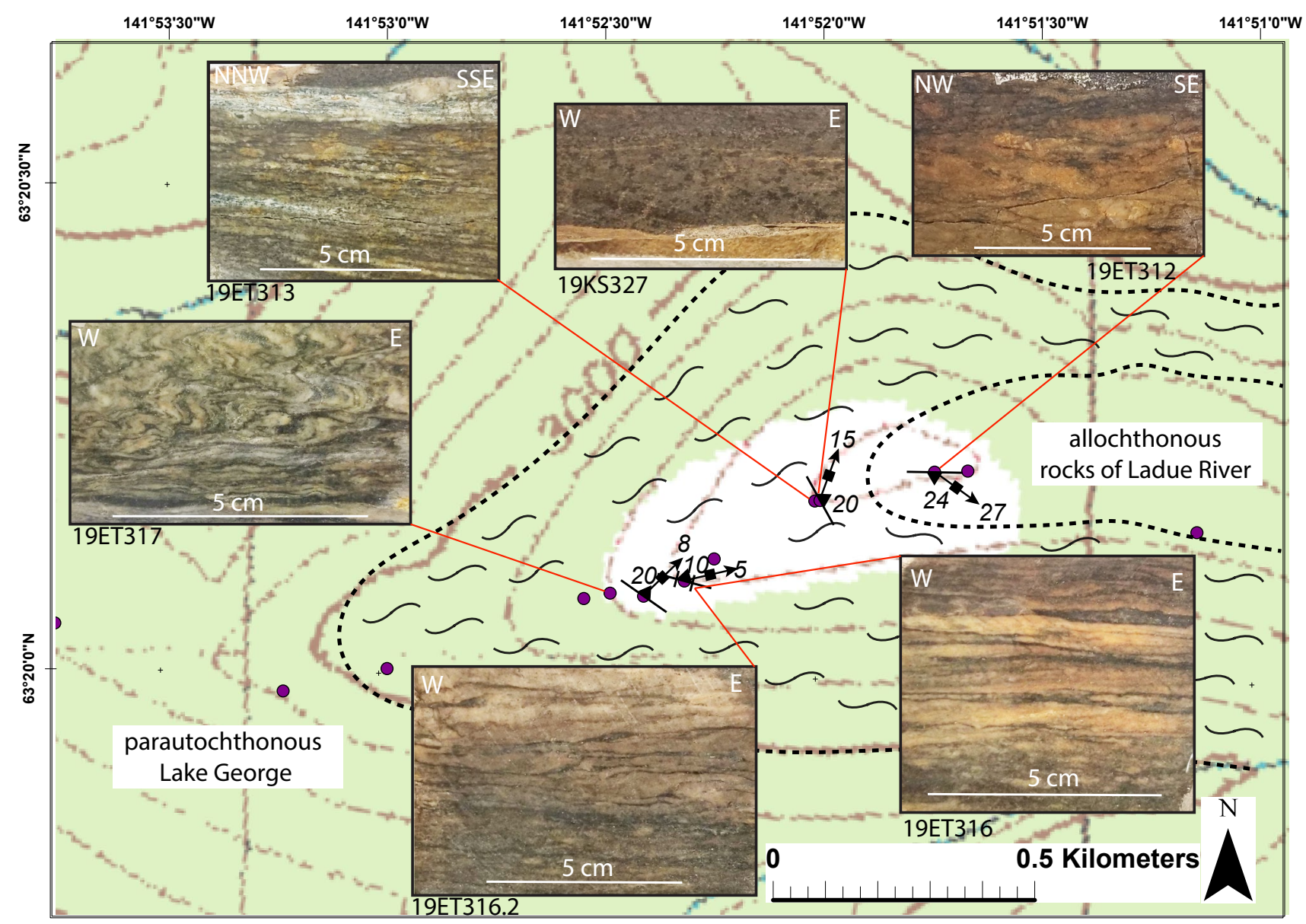

Figure 5. Mylonitic shear zone separating dominantly greenschist-facies allochthonous rocks of the Ladue River unit from the underlying amphibolite-facies (partially retrograded) Lake George assemblage. Field observations (sigma clasts, fold vergences) indicate top-to-the northeast shear sense.

from the allochthonous rocks of the Ladue River unit in that it never experienced metamorphic conditions above greenschist facies. Previous and current work suggest that the terranes are bound by low-angle ductile shear zones (Dusel-Bacon and others, 1995, 2002; Pavlis and others, 1993; Wypych and others, 2019). These shear zones may have accommodated both northwest-directed Jurassic thrusting, which placed the YTT structurally above parautochthonous North America, and southeast-directed mid-Cretaceous extension bringing the terranes to their present-day configuration (Hansen and Dusel-Bacon, 1998; DuselBacon and others, 2002; O'Neill and others, 2010).

Shear sense indicators are difficult to find in the map area due to poor exposure, and observed outcrops often have ambiguous or symmetrical kinematics. DGGS geologists located an outcropping shear zone separating the allochthonous rocks of the Ladue River unit from the underlying Lake George assemblage (fig. 5). Samples collected across this boundary have experienced varying degrees of grain-size reduction and range from protomylonitic to mylonitic in texture. Most kinematic indicators (mineral lineations, sigma clasts) suggest top-to-thenortheast shear sense. However, fold vergence observations and stretched mineral lineations suggest local top-to-the-northwest shear sense. There is evidence of within-assemblage shearing and mylonitization that is not associated with terrane or lithology unit boundaries, as illustrated in figure 6 . Within the Lake George assemblage, our mapping documents broadly distributed shear zone localities, typically 


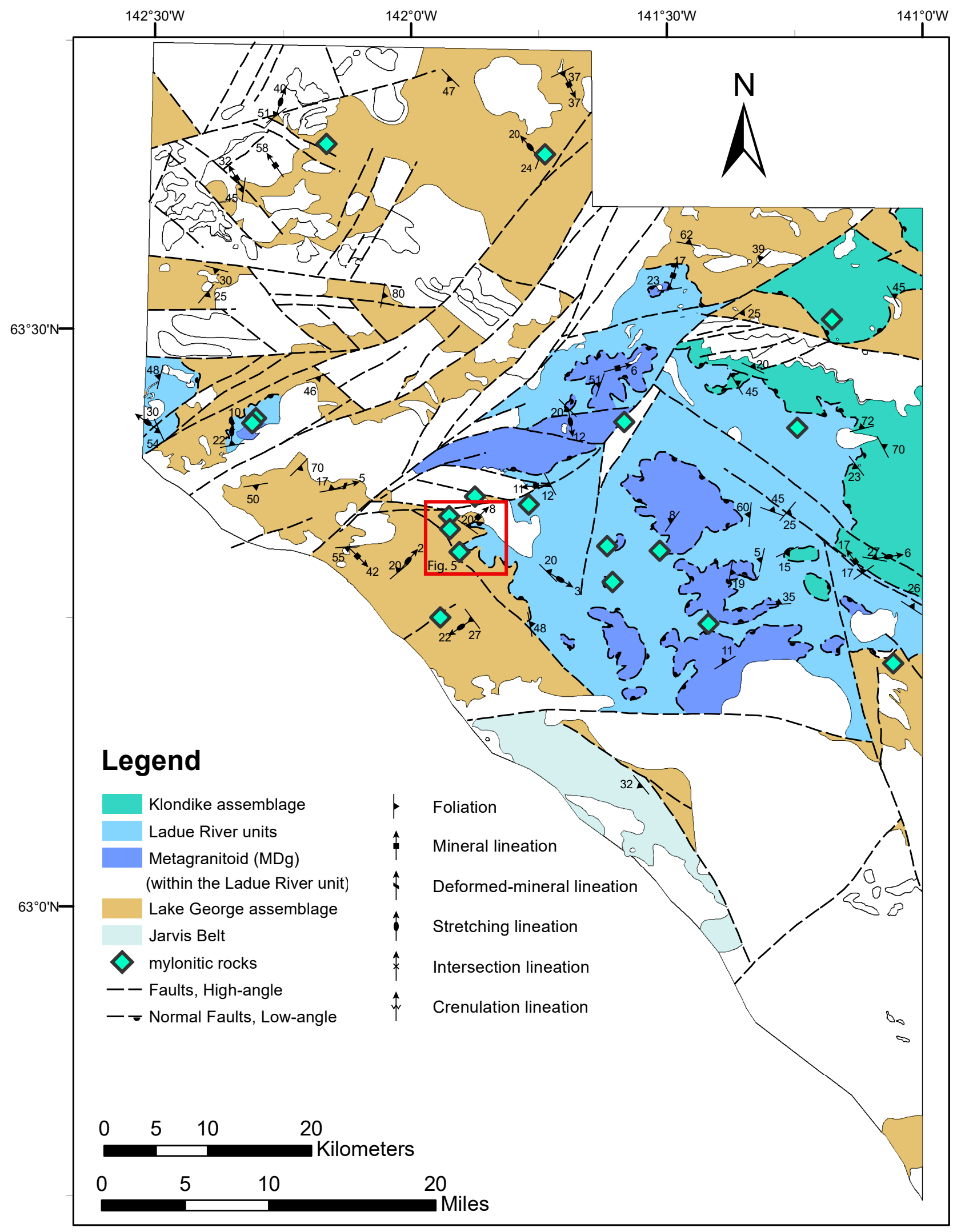

Figure 6. Map highlighting selected foliation and lineation measurements. Green diamonds are locations where shearing or mylonitization is recorded in field notes or observed in thin section. Red box shows location of shear zone illustrated in figure 5. 
with top-to-the-southeast motion based on kinematic indicators including sigma and delta clasts, shear bands, and stretching lineations of K-feldspar porphyroclasts (fig. 7A, B). This within-assemblage shearing may suggest a more complicated anastomosing behavior common within large-scale shear zones (Fossen and Cavalcante, 2017). The degree of connectivity between potential strands of a larger anastomosing shear zone is not well constrained given the lack of exposure.

Mylonitic foliations are generally oriented parallel to the main shallowly dipping folia- tions observed in the whole field area. However, one location east of Mount Fairplay recorded an anomalous steeply dipping mylonitic foliation with greenschist-facies mineralogy (station 19SPR196), which bisects the more dominant sub-horizontal foliation of a Lake George amphibolite-facies orthogneiss. This younger, lowergrade fabric has top-to-the-southeast kinematics consistent with the vergence of shallower tectonic components, but it has a much steeper down-dip stretching lineation which trends to the southeast (fig. 8).

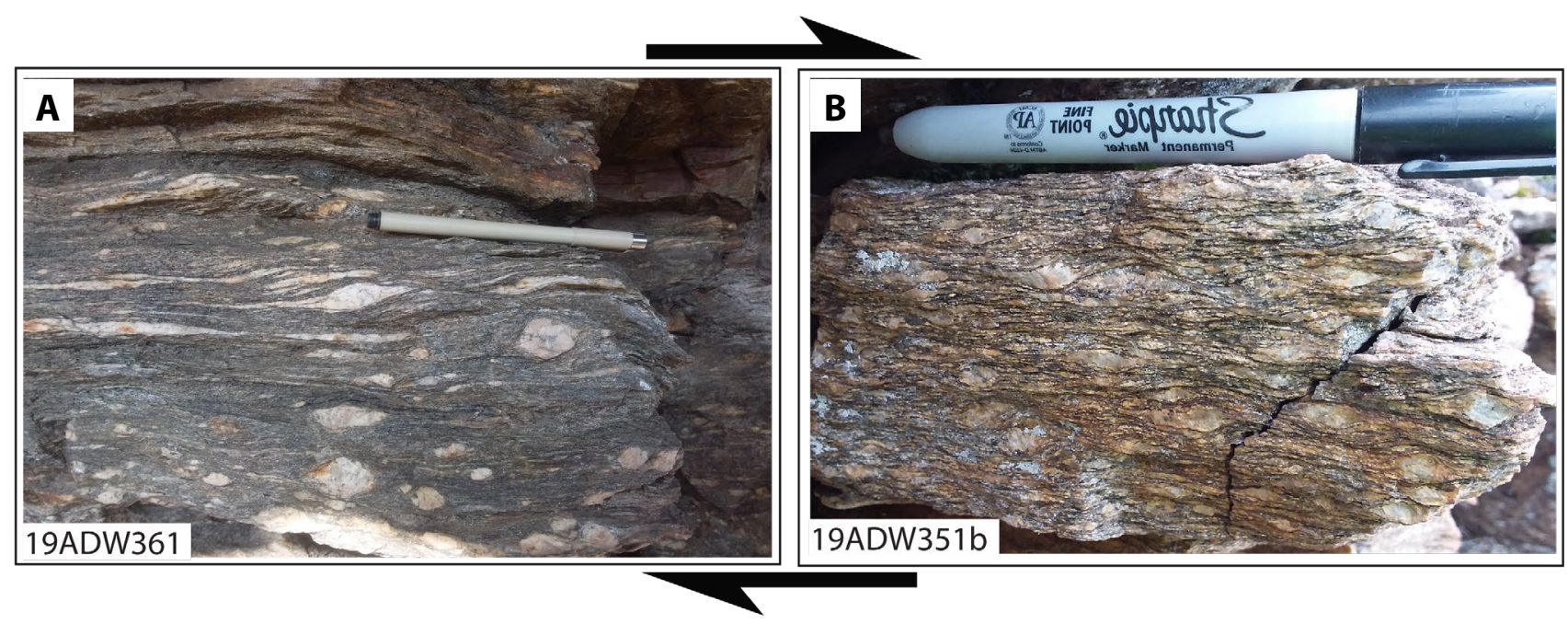

Figure 7. Examples of shear sense indicators and mylonitization from augen orthogneiss in the Lake George assemblage displaying top-to-the-southeast shear sense: (A) shear band; and, (B) sigma and delta clasts.

\section{Bedding}

Bedding measurements were collected in mid- to Late Cretaceous and Paleogene volcanic-volcaniclastic rocks with well-defined laminations or compaction layering. Bedding measurements within volcanic units are assumed to be indicators of paleohorizontal and our interpretations of post-eruption tilting of the volcanic units is built on the assumption that the volcanic beds were deposited horizontally. However, the volcanic air fall units could have bedding that more closely reflects paleotopography, especially if the units are relatively thin. Further observations of volcanic unit thickness and Cretaceous to Eocene paleoto- pography could validate these preliminary results. The volcanic units include the mid-Cretaceous West Fork felsic tuff (Kwff), Late Cretaceous felsic volcanic rocks (IKfv), Late Cretaceous alkaline volcanic rocks (IKav), and Paleogene rhyolite (Prr). Bedding observations within the West Fork felsic tuff (Kwff) and the felsic volcanic rocks (IKfv) on the west side of the map area near Mount Fairplay strikes between 160 and 260 degrees and dips shallowly to moderately to the northwest. At one locality, bedding within the felsic volcanic rocks (IKfv) dips slightly steeper with a similar strike (fig. 9A). This may indicate that little to no significant tilting occurred between the deposition of the West 

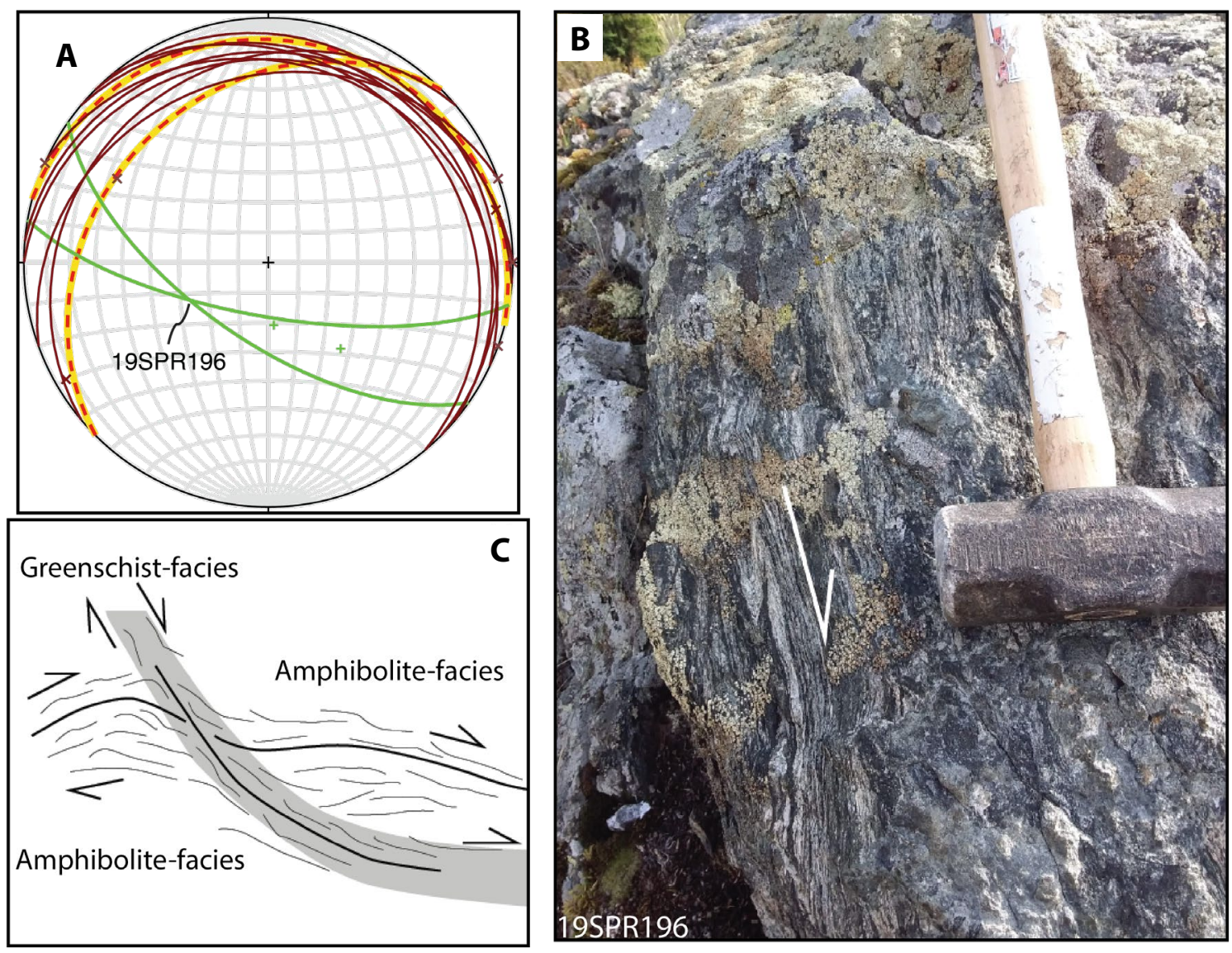

Figure 8. A closer look at samples $5 \mathrm{~km}$ east of Mount Fairplay displaying top-to-the-southeast kinematics of sample 19SPR196 and nearby dominant subhorizontal foliation found within the Lake George assemblage: (A) Equal-area stereonet plots of mylonitic greenschist-facies foliation of 19SPR196 (green) cutting dominant foliation (brown). Other Lake George mylonitic foliations from 40-50 km further southeast (shown by dashed red lines highlighted in yellow). "X's" and "plus signs" are corresponding mineral lineations; (B) 19SPR196 outcrop with shear sense; and, (C) Schematic of dominant Lake George foliation and kinematics with mylonitic greenschist-facies rock bisecting.

Fork felsic tuff Kwff (ca. 107.9 $\pm 0.3 \mathrm{Ma}$; sample 19TJN299; Wildland and others [2021]) and the felsic volcanic rocks IKfv $(-70-75 \mathrm{Ma}$ based on geochemical similarity to Late Cretaceous intrusions (IKfd; sample 19RN359; $70.5 \pm 0.8 \mathrm{Ma}$; Wildland and others, 2021). In the eastern map area near Yukon border, bedding orientations within the alkaline volcanic rocks (IKav) strike between 230 and 295 degrees and dip shallowly to moderately to the north-northwest, similar to nearby foliations of the Klondike assemblage (fig. 9b). One locality within the Paleogene rhyolite unit ( $\mathrm{REr}$ ) has a bedding measurement that plots within the dominant alkaline volcanic rocks (IKav) population. Another location strikes 330 degrees and dips more to the northeast. A third location has two bedding measurements that strike between 60 and 70 degrees and dip steeply to the southeast. These data may indicate that tilting of the alkaline volcanic rocks (IKav) occurred both before and after the Paleogene rhyolites were erupted and deposited at $58.7 \pm 0.2 \mathrm{Ma}$ (sample 19AW256; Wildland and others, 2021). Nearby high-angle east-westand northeast-southwest-striking faults are a likely explanation for the observed tilting in the eastern map area volcanic rocks.

\section{Dike and Vein Walls}

Andesitic to felsic dikes are common throughout the field area and typically have aphanitic to porphyritic textures. Dikes are often found 


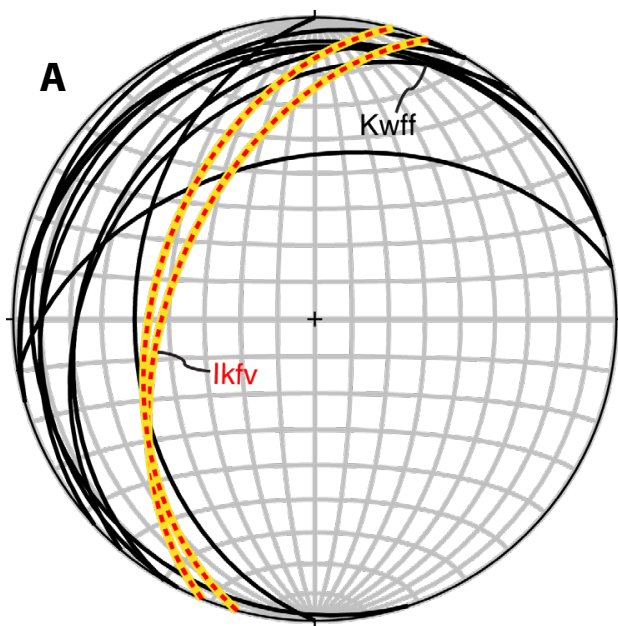

bedding (west area) Kwff: localities $=8 ; n=12$ lkfv: localities $=1 ; n=2$

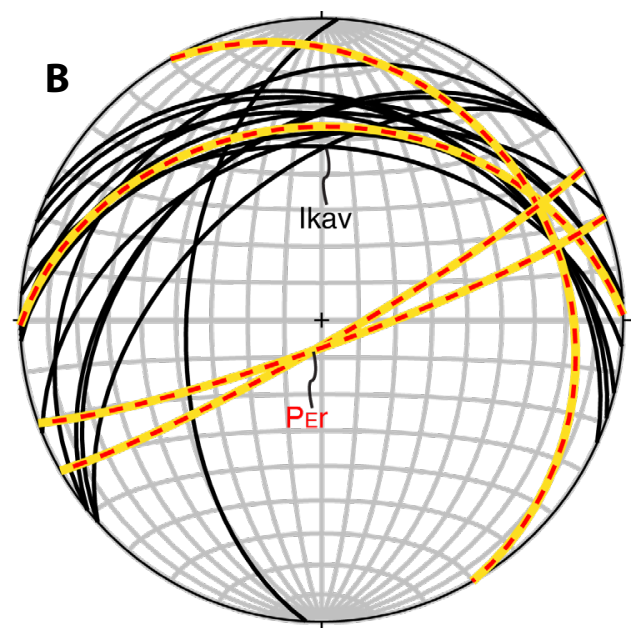

bedding (east area) Ikav: localities $=7 ; n=13$ Per: localities $=3 ; n=4$

Figure 9. Equal-area stereonet plot of bedding and compaction layering: (A) Bedding measurements in units Kwff (solid black lines) and IKfv (red and yellow dashed lines); and, (B) Bedding measurements in units IKav (solid black lines) and PEr (red and yellow dashed lines).

within, or neighboring, mid-Cretaceous plutons, similar to dike observations in the adjacent northeastern Tanacross map area (Wypych and others, 2019). Structurally, there appears to be no spatial or lithological pattern regarding dike orientations in this map area. Five dikes strike northeast-southwest and four strike northwest-southeast; all are moderately to steeply dipping (fig. 10A).

Vein walls are often parallel or subparallel to foliation and their measurements cluster in two populations (fig. 10B): (1) a cluster of northeast-trending high-angle planes (shown in red); and, (2) a group of shallowly dipping, northwest-striking measurements taken from a small area in the southeast corner of the map from a few different localities (shown in black) (stations: 19AW014; 19KS033; 19KS036). The northeast-trending veins have similar orientation to that of fractures and joints (discussed below) and the nearby Sixtymile-Pika fault zone.

\section{Faults and Fractures}

Due to limited exposure and recessive weathering of fault zones, only ten fault measurements were collected. A dominant northeast-south- west-striking set of faults were mapped in the area based on topography, geophysical surveys (Burns and others, 2020a,b), and observed lithology changes. Most measured fault orientations are high angle and strike north-south, an orientation that is not dominant on the map scale. Northeast-striking faults were recorded at stations $19 \mathrm{KS} 076$ and 19KS414 (fig. 11A). Where slickenlines were noted on a fault surface (19SPR081; quartz-rich felsic hypabyssal intrusion), they were described as a shear fracture surface with crescentic gouges indicating a steeply plunging down-dip lineation.

Orientation data of fracture and joint surfaces are summarized in figure 11 . The majority of poles to fracture and joint surface measurements trend northwest-southeast with moderate to shallow plunge (fig. 11B), but the diffuse preferred orientations are difficult to interpret. However, parsing by igneous rock units provides insight into preferred orientations within mid-Cretaceous plutons, Paleogene volcanic rocks, and the Mount Fairplay intrusive complex (fig. 11C). Joints and fracture surfaces within mid-Cretaceous plutons (pink diamonds) display two populations of mean vectors: 1) west-trending poles with steep plunge, and 

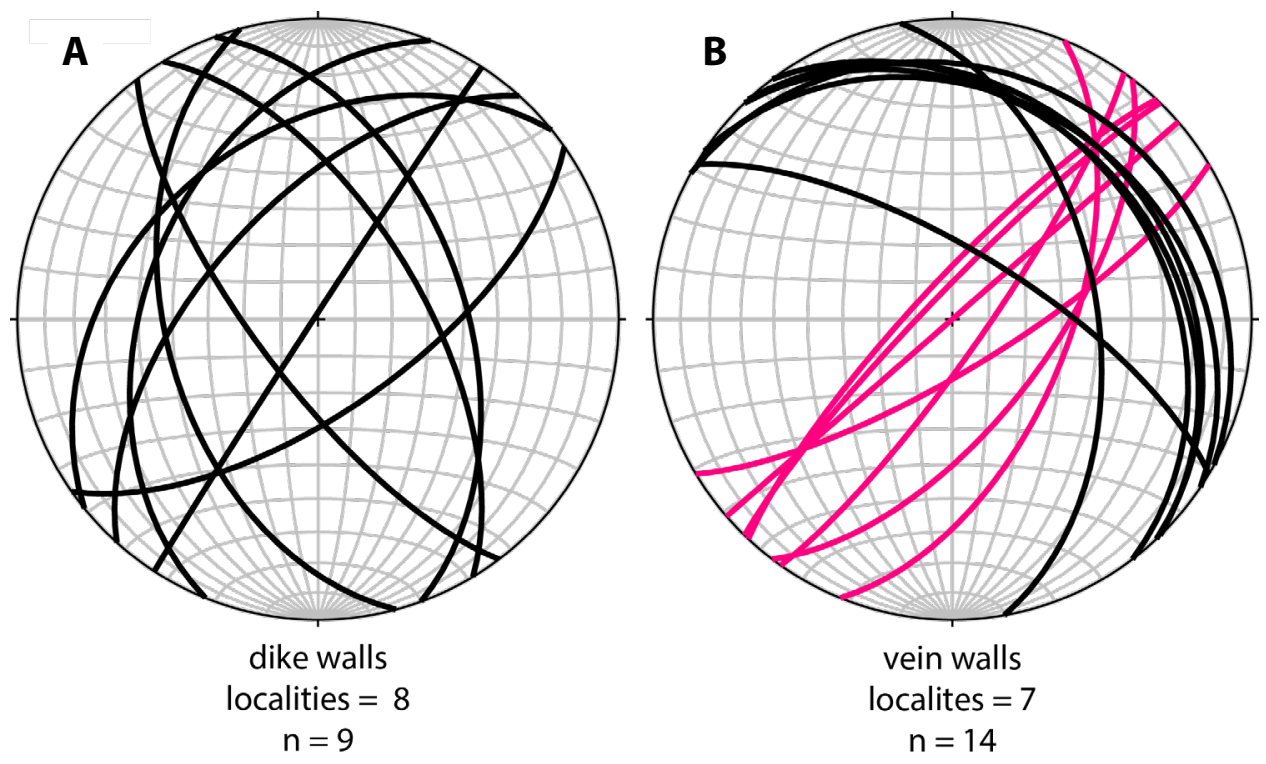

Figure 10. Equal-area stereonet plots: (A) dike walls; and, (B) vein walls. Northeast-striking measurements similar to joints observed near high-angle Sixtymile-Pika fault zone shown in pink.

2) northeast-trending poles with moderate plunge. The Paleogene volcanic rocks in the east side of the field area display a mean vector with northwest-trending poles with shallow-moderate plunge. Finally, joint-fracture data within the Mount Fairplay intrusions display southeast-trending poles with shallow plunge. Igneous rocks of other ages (Paleogene and Cretaceous), and remaining metamorphic assemblages (Ladue River unit and Klondike assemblage), either have insufficient data or no preferred orientation (fig. 11D).

\section{CONCLUSIONS}

Our foliation and folding observations are generally consistent with previous worker's interpretations (Hansen and Dusel-Bacon, 1998; Wypych and others, 2019). Metamorphic units record moderate to strong foliations that are subhorizontal to moderately dipping. This main foliation formed subsequent to an earlier generation of isoclinally folded foliations, suggesting at least two generations of foliation development. Mylonitic foliations are typically oriented parallel to the main shallowly dipping foliation. Ductile kinematic indicators within the Lake George assemblage dominantly record top-to-the-southeast shear, locally top-tothe-northwest (Hansen and Dusel-Bacon, 1998), and the structurally higher units of the YTT variably record both top-to-the-northwest and top-tothe-southeast shear, as previously noted by Hansen and Dusel-Bacon (1998). We also provide evidence of within-assemblage shearing and mylonitization that is not associated with terrane or lithology unit boundaries. Within the Lake George assemblage, our mapping documents broadly distributed shear zone localities, which suggest more complicated, possibly anastomosing, shear occurred below the YTT-Lake George boundary.

Additionally, we highlight that high-angle east-west and northeast-southwest striking faults are a likely explanation for the observed northward tilting of volcanic unit IKav and southward tilting of unit PEr, which occurred both before and after the Paleogene volcanics were erupted at $58.7 \pm 0.2$ Ma. Tilting does not seem to have occurred on all high-angle faults in the area, as volcanic units near the Taylor Highway experienced little apparent tilting between the deposition of Kwff (ca. 107.9 \pm $0.3 \mathrm{Ma})$ and IKfv $(-70-75 \mathrm{Ma})$. 


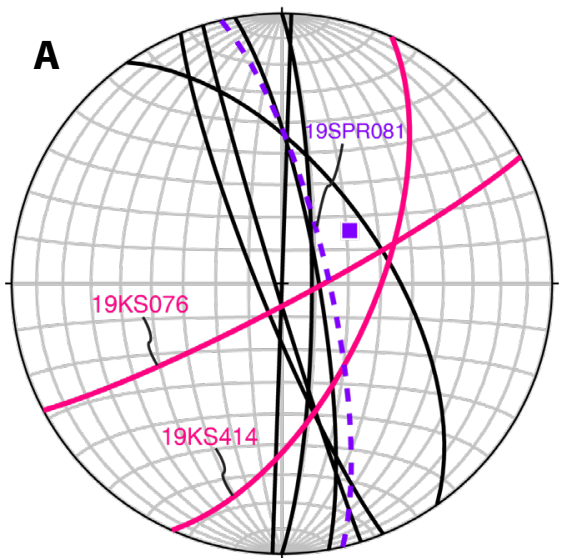

faults

localities $=4$

$\mathrm{n}=10$

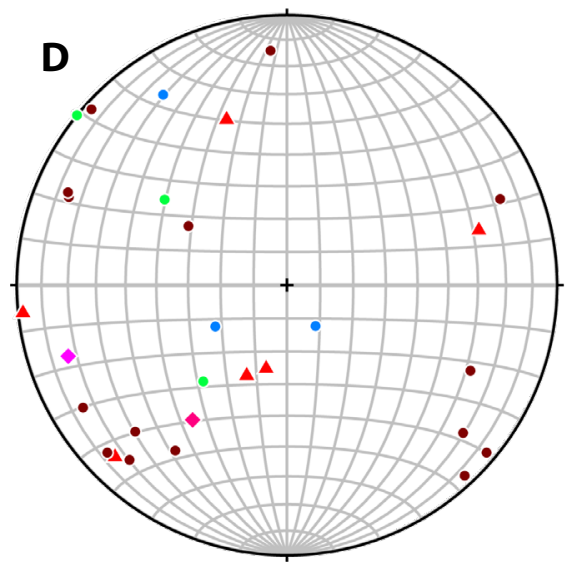

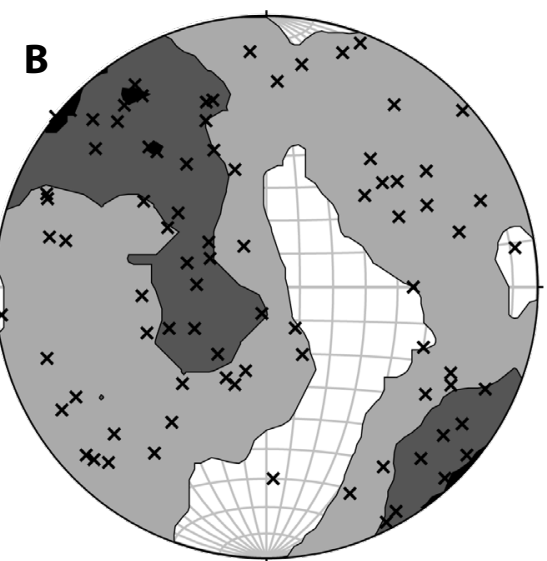

fractures and joints

localities $=28$

$\mathrm{n}=83$

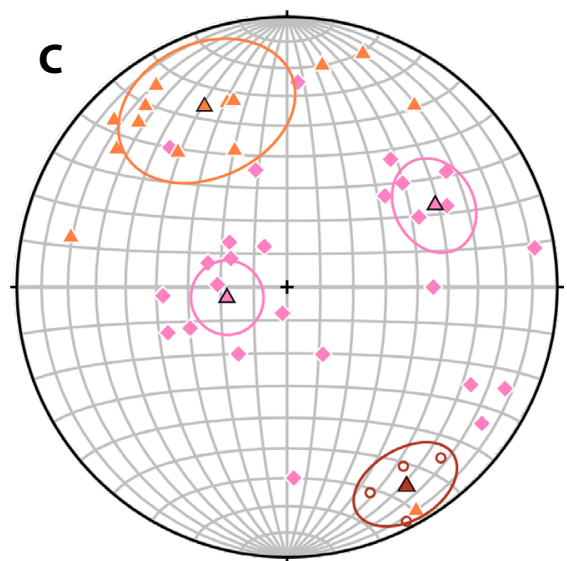

fractures and joints

mid-K plutons: localities $=5 ; \mathrm{n}=26$

Mt. Fairplay complex: localities $=1 ; n=4$

Paleogene volcanic: localities $=2 ; n=14$

Figure 11. Equal-area stereonet plots: (A) faults planes; purple dashed line and square represent fault plane with accompanying slickenline: trend $=52$, plunge $=64 ;(B)$ poles to fracture and joint surfaces. Kamb contour interval $=2 \sigma$; significance level = $3 \sigma$; and $(\mathbf{C})$ poles to fracture and joint surface orientations separated by rock unit. Mid-Cretaceous plutons (pink diamonds) mean vectors: 1) trend/plunge= 260.0; 71.6; and, 2) trend/plunge=61.0; 37.4. Paleogene volcanics mean vector with trend/plunge $=335.4 ; 27.4$. Mount Fairplay intrusion mean vector trend/plunge= 149; 15.1. (D) Map units with insufficient data or measurements with no preferred orientation.

\section{ACKNOWLEDGMENTS}

The authors would like to thank the DGGS Mineral Resources geologists and other DGGS staff who contributed data collection, scientific discussions, and other support. This project was jointly funded by the State of Alaska and the U.S. Geological Survey's Earth Mapping Resources Initiative (Earth MRI) through cooperative agreement G19AC00262. The views and conclusions contained in this document are those of the authors and should not be interpreted as representing the opinions or policies of the U.S. Geological Survey. Mention of trade names or commercial products does not constitute their endorsement by the U.S. Geological Survey.

Stereonet plots made with the Stereonet program by Cardozo and Allmendinger (2013). 


\section{REFERENCES}

Beranek, L.P. and Mortensen, J.K., 2011, The timing and provenance record of the Late Permian Klondike orogeny in northwestern Canada and arc-continent collision along western North America: Tectonics, v. 30, TC5017. https://doi. org/10.1029/2010TC002849

Berman, R.G., Ryan, J.J., Gordey, S.P. and Villeneuve, M., 2007, Permian to Cretaceous polymetamorphic evolution of the Stewart River region, Yukon-Tanana terrane, Yukon, Canada: P-T evolution linked with in situ SHRIMP monazite geochronology: Journal of Metamorphic Geology, v. 25, p. 803-827. https://doi-org.uaf.idm.oclc.org/10.1111/j.1525 -1314.2007.00729.x

Burns, L.E., Graham, G.R.C., Barefoot, J.D., Naibert, T.J., Fugro Airborne Surveys Corp., and Fugro GeoServices, Inc., 2020a, Ladue electromagnetic and magnetic airborne geophysical survey data compilation: Alaska Division of Geological \& Geophysical Surveys Geophysical Report 2019-20, 15 p. https://doi.org/10.14509/30261

Burns, L.E., Graham, G.E., Emond, A.M., Stevens Exploration Management Corp., and Fugro Airborne Surveys, 2020b, Alaska Highway corridor electromagnetic and magnetic airborne geophysical survey data compilation: Alaska Division of Geological \& Geophysical Surveys Geophysical Report 2020-15, 17 p. https://doi. org/10.14509/30462

Cardozo, Nestor, and Allmendinger, R.W., 2013, Spherical projections with OSXStereonet: Computers \& Geosciences, v. 51, p. 193-205. https://doi.org/10.1016/j.cageo.2012.07.021

Dusel-Bacon, Cynthia, Hansen, V.L., and Scala, J.A., 1995, High-pressure amphibolite facies dynamic metamorphism and the Mesozoic tectonic evolution of an ancient continental margin, east-central Alaska: Journal of Metamorphic Geology, v. 15, p. 9-24. https://doi.org/10.1111/j.1525-1314.1995. tb00202.x

Dusel-Bacon, Cynthia, Lanphere, M.A., Sharp, W.D., Layer, P.W., and Hanson, V.L., 2002, Mesozoic thermal history and timing of structural events for the Yukon-Tanana Upland, east-cen- tral Alaska- ${ }^{40} \mathrm{Ar} /{ }^{39} \mathrm{Ar}$ data from metamorphic and plutonic rocks: Canadian Journal of Earth Sciences, v. 39, n. 6, p. 1,013-1,051. https:// doi.org/10.1139/e02-018

Fossen, Haakon, and Cavalcante, G.C.G., 2017, Shear zones - A review; Earth-Science Reviews, v. 171, p. 434-455. https://doi.org/10.1016/j. earscirev.2017.05.002

Hansen, V.L., 1990, Yukon-Tanana terrane; a partial acquittal: Geology, v. 18, p. 365-369. https://dggs.alaska.gov/pubs/id/17433

Hansen, V.L., and Dusel-Bacon, Cynthia, 1998, Structural and kinematic evolution of the Yukon-Tanana Upland tectonites, east-central Alaska-A record of late Paleozoic to Mesozoic crustal assembly: Geological Society of America Bulletin, v. 110 , n. 2, p. 211-230. https:// doi.org/10.1130/0016-7606(1998)110<0211: SAKEOT > 2.3.CO;2

Jones, J.V., III and Benowitz, J.A., 2020, ${ }^{40} \mathrm{Ar} /{ }^{39} \mathrm{Ar}$ isotopic data and ages for rocks from the $\mathrm{Yu}$ kon-Tanana upland of eastern Alaska and the northern Aleutian Range of south-central Alaska: U.S. Geological Survey data release. https:// doi.org/10.5066/P96762V3

Jones, J.V., Todd, E., Caine, J.S., Holm-Denoma, C.S., Ryan, J.J. and Benowitz, J.A., 2017, October. Late Permian (CA. 267-257 MA) magmatism, deformation, and metamorphism and lithotectonic associations of the Ladue River Unit in east-central Alaska. In Geological Society of America Annual Meeting in Seattle, Washington, USA-2017. Geological Society of America.

Naibert, T.J., Benowitz, J.A., Wypych, Alicja, Sicard, K.R., and Twelker, Evan, 2020a, ${ }^{40} \mathrm{Ar} /{ }^{39} \mathrm{Ar}$ data from the Tanacross D-1 and parts of the D-2, C-1, and C-2 quadrangles, Alaska: Alaska Division of Geological \& Geophysical Surveys Raw Data File 2020-12, 35 p. https://doi. org/10.14509/30466

Naibert, T.J., Twelker, Evan, Wypych, Alicja, Athey, J.E., Newberry, R.J., Lopez, J.A., Regan, S.P., Sicard, K.R., Wildland, A.D., and Wyatt, W.C., 2020b, Field station locations and magnetic susceptibility data collected in 2019 for the Eastern Tanacross Project, Tanacross and Nabesna quad- 
rangles, Alaska: Alaska Division of Geological \& Geophysical Surveys Raw Data File 2019-9, 2 p. https://doi.org/10.14509/30268

O'Neill, J.M., Day, W.C., Aleinikoff, J.N., and Saltus, R.W., 2010, The Black Mountain tectonic zone-a reactivated northeast trending crustal shear zone in the Yukon-Tanana Upland of east-central Alaska, in Gough, L.P., and Day, W.C., eds., Recent U.S. Geological Survey studies in the Tintina Gold Province, Alaska, United States, and Yukon, Canada-results of a 5 year project: U.S. Geological Survey Scientific Investigations Report 2007-5289-D, p. D1-D8.

Pavlis, T.L., 1989, Middle Cretaceous orogenesis in the northern Cordillera: A Mediterranean analog of collision-related extensional tectonics: Geology, v. 17, p. 947-950.

Pavlis, T.L., Sisson, V.B., Foster, H.L., Nokleberg, W.J., and Plafker, George, 1993, Mid-Cretaceous extensional tectonics of the Yukon-Tanana Terrane, Trans-Alaska Crustal Transect (TACT), east-central Alaska: Tectonics, v. 12, p. 103-122. https://doi.org/10.1029/92TC00860

Solie, D.N., Werdon, M.B., Freeman, L.K., Newberry, R.J., Szumigala, D.J., Speeter, G.G., and Elliott, B.A., 2019, Bedrock-geologic map, Alaska Highway corridor, Tetlin Junction, Alaska to Canada border: Alaska Division of Geological \& Geophysical Surveys Preliminary Interpretive Report 2019-3, 16 p., 2 sheets, scale 1:63,360. http://doi.org/10.14509/30038

Staples, R.D., H.D. Gibson, Colpron, Maurice, and Ryan, J.J., 2016, An orogenic wedge model for diachronous deformation, metamorphism, and exhumation in the hinterland of the northern Canadian Cordillera: Lithosphere; v. 8, n. 2, p. 165-184. https://doi.org/10.1130/L472.1

Twelker, Evan, Newberry, R.J., Wypych, Alicja, Naibert, T.J., Wildland, A.D., Sicard, K.R., Regan, S.P., Athey, J.E., Wyatt, W.C., and Lopez, J.A., 2021, Bedrock geologic map of the Ladue River-Mount Fairplay area, Tanacross and Nabesna quadrangles, Alaska, in Twelker, Evan, ed., Geologic investigation of the Ladue River-Mount Fairplay area, eastern Alaska: Alaska Division of Geological \& Geophysical Surveys Report of Investigation 2021-5A. https://doi. org/10.14509/30735

Wildland, A.D., Wypych, Alicja, Regan, S.P., and Holland, Mark, 2021, U-Pb zircon ages from bedrock samples collected in the Tanacross and Nabesna quadrangles, eastern Alaska: Alaska Division of Geological \& Geophysical Surveys Preliminary Interpretive Report 2021-4, 47 p. https://doi.org/10.14509/30732

Wypych, Alicja, Hubbard, T.D., Naibert, T.J., Athey, J.E., Newberry, R.J., Sicard, K.R., Twelker, Evan, Werdon, M.B., Willingham, A.L., Wyatt, W.C., and Lockett, A.C., 2019, Northeastern Tanacross geologic map, Tanacross D-1, D-2, C-1, and C-2 quadrangles, Alaska: Alaska Division of Geological \& Geophysical Surveys Preliminary Interpretive Report 2019-6, 20 p., 1 sheet, scale 1:63,360. https://doi.org/10.14509/30197 